\title{
Synthesis of New Nitrofluoroquinolone Derivatives with Novel Anti-Microbial Properties against Metronidazole Resistant H. pylori
}

\author{
Luay Abu-Qatouseh 1,*, Mohammad Abu-Sini 2,3, Amal Mayyas ${ }^{4}$, Yusuf Al-Hiari ${ }^{2}$, \\ Rula Darwish ${ }^{2}$ and Talal Aburjai ${ }^{2}$ \\ 1 Faculty of Pharmacy, University of Petra, 11914 Amman, Jordan \\ 2 Faculty of Pharmacy, University of Jordan, 11914 Amman, Jordan; \\ mohammad.abusini@zuj.edu.jo (M.A.-S.); hiary@ju.edu.jo (Y.A.-H.); \\ rulad@ju.edu.jo (R.D.); aburjai@ju.edu.jo (T.A.) \\ 3 Faculty of Pharmacy, Al-Zaytoonah University of Jordan, 11733 Amman, Jordan \\ 4 Faculty of Health Sciences, American University of Madaba, 11821 Madaba, Jordan; a.mayyas@aum.edu.jo \\ * Correspondence: labuqatouseh@uop.edu.jo; Tel.: +962-79-701-2082 \\ Academic Editor: Diego Muñoz-Torrero \\ Received: 6 November 2016; Accepted: 28 December 2016; Published: 4 January 2017
}

\begin{abstract}
One of the major therapeutic approaches to preventing relapse and accelerating the healing of duodenal and gastric ulcers is the eradication of Helicobacter pylori. Due to the emergence of antibiotic resistance among clinical strains of $H$. pylori, alternative approaches using newly discovered antimicrobial agents in combination with the standard regimens for the treatment of H. pylori are increasingly needed. The purpose of the present study was to investigate the effect of newly synthesized 8-nitroflouroqunolone derivatives when used either alone or when combined with metronidazole against metronidazole-resistant $H$. pylori. Based on the standard antimicrobial susceptibility testing methods and checkerboard titration assay, all of the tested compounds showed interesting antimicrobial activity against 12 clinical strains of $H$. pylori, with the best in vitro effect for compound 3c. In addition, synergistic and additive activities of some of the tested compounds were observed when combined with metronidazole. Furthermore, among the tested nitroflouroquinolone derivatives, compound $3 \mathbf{b}$ showed significant urease inhibition activity with $\mathrm{IC}_{50}$ of $62.5 \mu \mathrm{g} / \mathrm{mL}$. These results suggest that 8-nitroflouroquinolone derivatives may have a useful role in combination with anti-H. pylori drugs in the management of $H$. pylori-associated diseases.
\end{abstract}

Keywords: nitrofluoroquinolones; $H$. pylori; urease inhibition

\section{Introduction}

Helicobacter pylori has been increasingly emerging as a major cause of chronic gastritis and peptic ulcer worldwide [1,2]. Furthermore, H. pylori colonization of the gastric mucosa constitutes a major risk factor in the pathogenesis of gastric cancer and gastric mucosa-associated lymphoid tissue (MALToma) [3-5]. The eradication of H. pylori and/or attenuating its associated virulence factors can therefore contribute to improving the clinical conditions of patients infected with this bacterium, including the acceleration of peptic ulcer healing and minimizing the recurrence of gastric cancer [6]. Current approaches for the effective eradication of $H$. pylori include the use of at least two antibiotics and a proton pump inhibitor (triple and more recently quadruple therapy) $[7,8]$. However, due to the emergence of antibiotic resistance among $H$. pylori clinical strains-particularly against metronidazole and clarithromycin-higher rates of treatment failure of triple therapy have been reported $[9,10]$. Therefore, a search for new approaches with high efficacy and safety against $H$. pylori infection is necessary. 
Since their discovery, fluoroquinolones have been extensively considered as major successful therapeutic antibacterial and anticancer agents [11-14]. However, a low level of resistance against fluoroquinolones among $H$. pylori clinical strains has been reported $[15,16]$. In a previous work, the biological activities of a group of 8-nitrofluoroquinolone derivatives have been evaluated, and strong antibacterial effect against Escherichia coli and Staphylococcus aureus was observed [17,18].

In general, the synthesis of novel C-7-substituted derivatives of 1-cyclopropyl-6-fluoro-8-nitro4-oxo-1,4-dihydroquinoline-3-carboxylic acid having an 8-nitro substituent as an electron withdrawing group was evaluated for biological activity. In the present study, the antibacterial activity of previously described 8-nitrofluoroquinoline derivatives and two newlysynthesized 8-nitrofluoroquinolone derivatives was tested against twelve clinical strains and one control strain of $H$. pylori which are resistant to metronidazole. In addition, the effect of the potentially effective derivatives in combination with metronidazole against metronidazole-resistant $H$. pylori strains was evaluated.

\section{Results and Discussion}

\subsection{Synthesis of New Compounds}

Synthesis of ester 1 was conducted following a previously reported procedure with good yields [18]. Compounds 2a-e were synthesized by the reaction of substituted anilines with compound 1 under reflux (Scheme 1). Methoxy $2 \mathrm{c}$ was obtained in higher yields compared to other derivatives.Hydrolysis of nitro ester $\mathbf{2}$ generated nitro acid target 3 . Compounds $\mathbf{2}$ and $\mathbf{3 a}-\mathbf{e}$ were identified and characterized by infrared spectroscopy (IR), mass spectrometry (MS), and ${ }^{1} \mathrm{H}$ - and ${ }^{13} \mathrm{C}-\mathrm{NMR}$ spectroscopic analyses. The data for $\mathbf{2} \mathbf{b}, \mathbf{c}$ and $\mathbf{3 b}, \mathbf{c}$ are presented in the experimental section, since they were the most active.

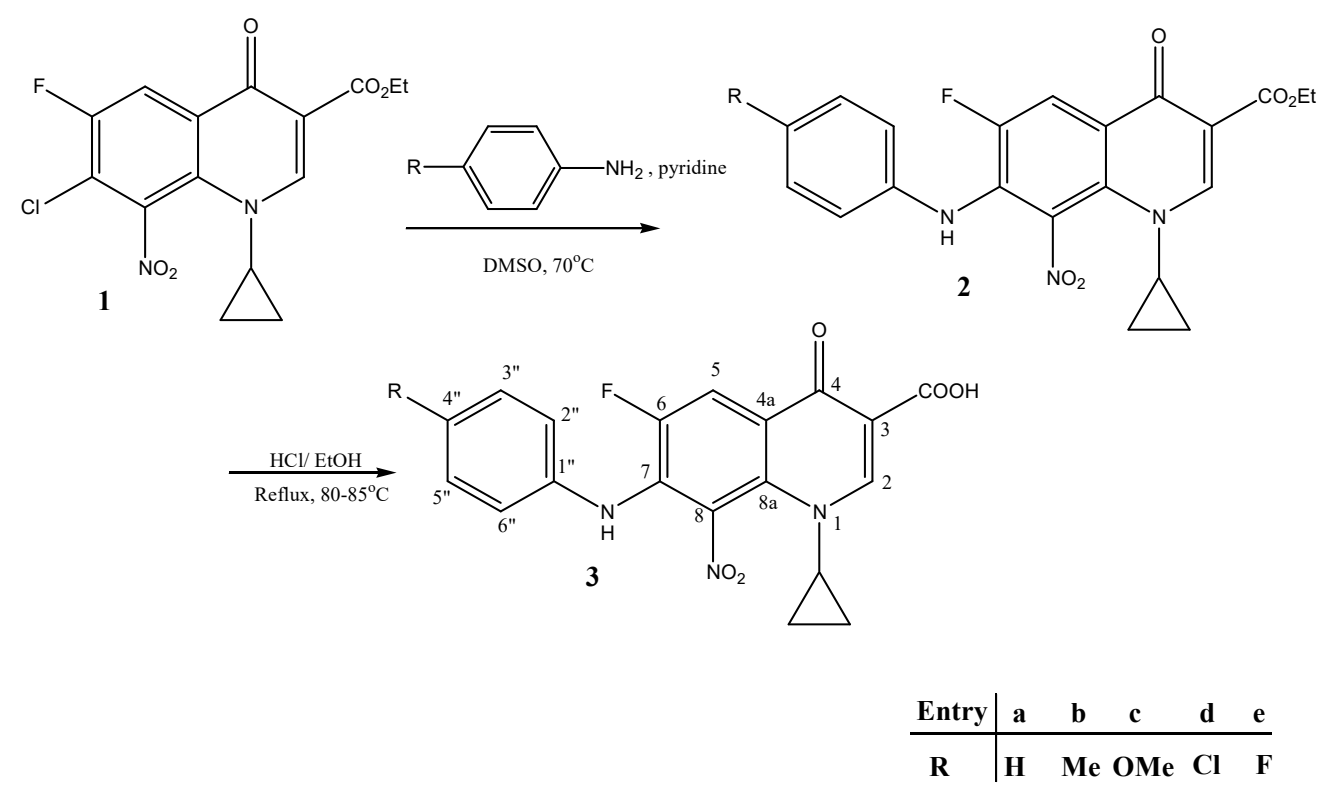

Scheme 1. General procedure for the synthesis of novel target compounds 3(a-e). DMSO: dimethylsulfoxide.

The ${ }^{1} \mathrm{H}-\mathrm{NMR}$ spectra of all synthesized compounds (3a-e) contained a doublet for H-5 $\left(3 J_{\mathrm{H}-\mathrm{F}}=10-13 \mathrm{~Hz}\right)$ at $\sim 8.0 \mathrm{ppm}$. The splitting of this signal was caused by the vicinal fluorine, and indicated the presence of the fluoroquinolone nucleus in all of these compounds. Similarly, the singlet for H-2 at $\sim 9.0$ ppm effectively confirmed that compound 3 had been successfully formed. The ${ }^{1} \mathrm{H}-\mathrm{NMR}$ spectra of the side chain of 3a-e contained new singlets in the range of 2.3-3.7 ppm and broad singlets in the range of $6.5-8.7 \mathrm{ppm}$, which were assigned to the aromatic methyl or methoxy 
and $\mathrm{NH}$, respectively. The appearance of new peaks in the ranges of 6.8-7.2 ppm corresponding to the aromatic side chain protons was further proof. These signals effectively confirmed that the aryl amine side chains had been effectively incorporated into compound 3 . The appearance of a new peak above $12 \mathrm{ppm}$ in 3 accompanied by the parallel disappearance of the triplet, quartet pattern for ester derivative 2 indicated the success of the hydrolysis step.

All of the carbons belonging to arylamine side chains were recognizable by their number, position, and orientation in depth charts in the aliphatic region. These signals confirmed that the arylamine chains had been successfully incorporated in compounds 3a-e, further confirmation was noticed by the appearance of methyl and methoxy peaks within aliphatic regions. For the fluoroquinolone part, the ${ }^{13} \mathrm{C}-\mathrm{NMR}$ spectra of compounds $3 \mathbf{a}-\mathbf{e}$ contained a doublet $\left(1 J_{\mathrm{C}-\mathrm{F}}=250 \mathrm{~Hz}\right)$ at $\sim 150 \mathrm{ppm}$ for C-6, which indicated the presence of the fluoroquinolone (FQ) nucleus in all of these compounds. This was also confirmed from depth analysis. The splitting of the neighboring carbon signals at C-5 and C-7 into doublet peaks in these compounds $\left(2 J_{\mathrm{C}-\mathrm{F}} \sim 20 \mathrm{~Hz}\right)$ effectively confirmed that they were all vicinal to a fluorine atom.

High- and low-resolution mass analysis was carried out for most compounds, and confirmed the expected compounds. $(M+1)$ molecular peak was obtained in most cases. Some cases had witnessed the appearance of $(\mathrm{M}+2)$ molecular peaks due to bad tuning of the detector. This phenomenon can be also referred to the presence of multiple nitrogen atoms of the expected compounds. Positive mode of ionization adopted in the analysis procedure renders nitrogen atoms in their protonated form. Infrared spectroscopy was carried out for all compounds. Characteristic peaks of carbonyl, hydroxyl, amino, $\mathrm{N}=\mathrm{N}$, and $\mathrm{C}-\mathrm{X}$ confirmed the identity of the expected compounds.

\subsection{Antimicrobial Activity against Metronidazole-Resistant H. pylori}

Previous work on the antimicrobial activity of 8-nitrofluoroquinolones reported variation in the potency of the tested compounds against Gram positive and Gram negative bacteria. It has been suggested in our group that the variable activity of these compounds could be related to the hydrophobic/hydrophilic properties of their structures, with no specific pattern [17,18].

H. pylori possesses unique biological characteristics among all eubacteria. Being a microaerophilic slow growing microorganism would dictate different activities of the antimicrobial agents against this pathogen, particularly in vivo. In this study, 8-nitrofluoroquinolone derivatives were evaluated for their antimicrobial properties against clinical strains of $H$. pylori. The initial screening showed that all of the tested compounds had antimicrobial activity against $H$. pylori, with a potent effect of compound $3 \mathbf{c}$ (Table 1). The minimum inhibitory concentration (MIC) values of the tested compounds against the clinical strains were in the range of $2-64 \mu \mathrm{g} / \mathrm{mL}$, which are higher than ciprofloxacin (Table 2). The best activity was reported for compound $\mathbf{3 c}$, followed by compounds $\mathbf{3 a}$ and $\mathbf{3 d}$, respectively.

Table 1. Zones of inhibition (mm) of synthesized compounds ( $1 \mathrm{mg} / \mathrm{mL})$, ciprofloxacin, and metronidazole against clinical strains of H. pylori (1-12) and control strain.

\begin{tabular}{|c|c|c|c|c|c|c|c|c|c|c|c|c|c|}
\hline \multirow{3}{*}{ Tested Compound } & \multicolumn{13}{|c|}{ Zones of Inhibition (mm) } \\
\hline & \multicolumn{12}{|c|}{ Clinical Isolates } & \multirow{2}{*}{ Control Strain } \\
\hline & 1 & 2 & 3 & 4 & 5 & 6 & 7 & 8 & 9 & 10 & 11 & 12 & \\
\hline $3 a$ & 10 & 20 & 15 & 10 & 20 & 11 & 11 & 17 & 9 & 15 & 13 & 15 & 18 \\
\hline $3 b$ & 12 & 12 & 0 & 15 & 11 & 16 & 13 & 15 & 11 & 12 & 14 & 13 & 12 \\
\hline $3 c$ & 20 & 24 & 20 & 16 & 24 & 20 & 18 & 25 & 15 & 20 & 23 & 25 & 25 \\
\hline $3 d$ & 10 & 10 & 8 & 12 & 13 & 11 & 14 & 15 & 9 & 14 & 13 & 12 & 12 \\
\hline $3 e$ & 10 & 12 & 0 & 15 & 15 & 14 & 12 & 16 & 9 & 15 & 15 & 14 & 13 \\
\hline CIP & 20 & 40 & 0 & 40 & 50 & 45 & 50 & 0 & 0 & 45 & 50 & 45 & 45 \\
\hline MTZ & 10 & 0 & 0 & 0 & 0 & 10 & 0 & 0 & 0 & 0 & 0 & 0 & 0 \\
\hline DMSO & 0 & 0 & 0 & 0 & 0 & 0 & 0 & 0 & 0 & 0 & 0 & 0 & 0 \\
\hline
\end{tabular}

CIP: ciprofloxacin; MTZ: metronidazole. 
Table 2. Minimum inhibitory concentration (MIC, $\mu \mathrm{g} / \mathrm{mL}$ ) of tested compounds and metronidazole against clinical strains of $H$. pylori (1-12) and control strain by two-fold agar dilution method.

\begin{tabular}{|c|c|c|c|c|c|c|c|c|c|c|c|c|c|}
\hline \multirow{3}{*}{ Compounds } & \multicolumn{13}{|c|}{ Minimum Inhibitory Concentration $(\mu \mathrm{g} / \mathrm{mL})$} \\
\hline & \multicolumn{12}{|c|}{ Strain Number } & \multirow{2}{*}{ Control Strain } \\
\hline & 1 & 2 & 3 & 4 & 5 & 6 & 7 & 8 & 9 & 10 & 11 & 12 & \\
\hline $3 a$ & 32 & 16 & 16 & 16 & 8 & 32 & 16 & 8 & 16 & 32 & 16 & 16 & 16 \\
\hline $3 b$ & 32 & 32 & 16 & 32 & 32 & 64 & 32 & 32 & 32 & 32 & 32 & 32 & 32 \\
\hline $3 c$ & 4 & 4 & 8 & 4 & 2 & 4 & 4 & 8 & 4 & 4 & 8 & 4 & 8 \\
\hline $3 d$ & 32 & 16 & 16 & 16 & 32 & 32 & 16 & 16 & 32 & 32 & 16 & 32 & 16 \\
\hline $3 e$ & 16 & 32 & 32 & 16 & 32 & 32 & 16 & 32 & 32 & 32 & 16 & 32 & 32 \\
\hline CIP & 0.3 & 0.6 & 0.3 & 0.6 & 0.3 & 0.04 & 0.6 & 0.04 & 0.08 & 0.04 & 0.6 & 0.6 & 0.6 \\
\hline MTZ & 64 & 64 & 64 & 32 & 128 & 64 & 128 & 32 & 64 & 64 & 128 & 64 & 128 \\
\hline
\end{tabular}

In terms of the antimicrobial effects of the combinations of the tested compounds with metronidazole against the metronidazole-resistant strains, our study reported interesting synergistic activity of the metronidazole $3 \mathbf{a}$ and metronidazole $\mathbf{3 d}$ combinations with fractional inhibitory concentration (FIC) indices of 0.328 , although these compounds when tested alone showed moderate activity against the tested strains. It could be suggested that these compounds might work on the cell membrane of $H$. pylori, making it more permeable to metronidazole, since these compounds have some hydrophilic properties. Metronidazole is reduced to disrupt energy metabolism of anaerobes by hindering the replication, transcription, and repair process of DNA results in cell death (i.e., it inhibits nucleic acid synthesis by disrupting the DNA of microbial cells). Although metronidazole is a low molecular weight compound that diffuses across cell membranes, facilitating its entry and achieving an adequate concentration at its site of action would result in better effects on the bacteria, and this is done by using compoundswhich have some hydrophilic properties. Moreover, the combination of metronidazole $+3 \mathbf{c}$ and metronidazole $+3 \mathbf{e}$ showed an additive effect, with FIC indices of 0.656 and 0.874 , respectively (Table 3 ). The combination of metronidazole $+3 \mathbf{b}$ showed indifferent activity with FIC indices of 1.312, providing that compound $3 \mathbf{b}$ reported the least antimicrobial effect against the studied strains when tested alone.

Table 3. Fractional inhibitory concentration (FIC) values of tested compounds in combination with metronidazole against clinical strains of H. pylori $(\mathbf{1 1}, \mathbf{1 2})$ and control strain by standard checkerboard titration method with two-fold serial agar dilutions.

\begin{tabular}{ccccc}
\hline \multirow{2}{*}{ Compounds } & \multicolumn{3}{c}{ FIC Values (Index) (MIC Combination) } & \multirow{2}{*}{ FIC Mean } \\
\cline { 2 - 3 } & \multicolumn{3}{c}{ Strain Number } & \\
\cline { 2 - 4 } 3a-MTZ & $\begin{array}{c}0.328\left(^{*}\right) \\
(2.5)\end{array}$ & $\begin{array}{c}0.328\left(^{*}\right) \\
(2.5)\end{array}$ & $\begin{array}{c}0.328\left(^{*}\right) \\
(2.5)\end{array}$ & $0.328\left(^{*}\right)$ \\
\hline 3b-MTZ & $\begin{array}{c}1.312(=) \\
(10)\end{array}$ & $\begin{array}{c}1.312(=) \\
(10)\end{array}$ & $\begin{array}{c}1.312(=) \\
(10)\end{array}$ & \multirow{2}{*}{ Control Strain } \\
\hline 3c-MTZ & $\begin{array}{cccc}0.656(+) \\
(5)\end{array}$ & $\begin{array}{c}0.656(+) \\
(5)\end{array}$ & $\begin{array}{c}0.656(+) \\
(5)\end{array}$ & $0.656(+)$ \\
\hline 3d-MTZ & $\begin{array}{c}0.328\left(^{*}\right) \\
(2.5)\end{array}$ & $\begin{array}{c}0.328\left(^{*}\right) \\
(2.5)\end{array}$ & $\begin{array}{c}0.328\left(^{*}\right) \\
(2.5)\end{array}$ & $0.328\left(^{*}\right)$ \\
\hline 3e-MTZ & $\begin{array}{c}1.312(=) \\
(10)\end{array}$ & $\begin{array}{c}0.656(+) \\
(5)\end{array}$ & $\begin{array}{c}0.656(+) \\
(5)\end{array}$ & $0.874(+)$ \\
\hline
\end{tabular}

$\left({ }^{*}\right)$ : Synergism; (+): Additive; (=): Indifferent. 


\subsection{Inhibitory Effects of the Synthesized Compounds against H. pylori Urease Enzyme}

One of the new potentials for the control of H. pylori infections is to reduce its pathogenicity by targeting its virulence factors [19]. The urease enzyme is a major virulence factor of $H$. pylori required for the optimal colonization and survival of this pathogen in the acidic conditions of the human stomach [20]. In this study, 8-nitrofluoroquinolones were evaluated for their potential inhibitory effect against $H$. pylori urease. The compounds were tested for their inhibitory effects in the range of $0.5-500 \mu \mathrm{g} / \mathrm{mL}$ by the standard colorimetric method mentioned above, and the compounds that showed less than $60 \%$ inhibition were considered to have no significant effect [20]. Our work showed that significant urease inhibition effect was reported only for compounds $\mathbf{3 b}$ and $\mathbf{3} \mathbf{c}$, with higher inhibitory effect for $3 \mathrm{c}$ with $\mathrm{IC}_{50}$ value of $62.5 \mu \mathrm{g} / \mathrm{mL}$ (Table 4). This unique inhibitory effect of the methyl and methoxy derivatives might be due to allosteric action against the enzyme, and needs to be further investigated.

Table 4. Urease inhibition activity of the synthetic compounds. All compounds tested in the concentration range of $0.5-500 \mu \mathrm{g} / \mathrm{mL}$. The effect was considered significant if the inhibition was more than $60 \%$. Acetohydroximic acid (AHA) was used as positive control. NS = not significant.

\begin{tabular}{cc}
\hline Compound & $\mathrm{IC}_{\mathbf{5 0}}(\boldsymbol{\mu M})$ \\
\hline 3a & NS \\
3b & 629 \\
3c & 151 \\
3d & NS \\
3e & NS \\
AHA & 27 \\
\hline
\end{tabular}

\subsection{Structural Activity Relationship Studies}

The results of this research reveal that $3 \mathbf{c}$ (para methoxy aniline substituents) exhibited significant inhibitory activity against $H$. pylori. An attempt was carried out to understand the underlying structural effect of these compounds. Esters $\mathbf{1}$ and $\mathbf{2 c}$ were both evaluated for their antimicrobial properties against clinical strains of $H$. pylori, demonstrating no activity. At this early stage of research, we can suggest that activity of these FQs (3a-c) lies mainly within the 4-oxo-pyridine-3-carboxylic acid system. Losing the free $\mathrm{COOH}$ group in 2 condensed the activity significantly. It was noticed that ester $2 \mathrm{c}$ is higher in its activity than $\mathbf{1}$, which lacks any substituent at C7-although both have low activity against H. pylori. This finding designates that increasing lipophilicity through aniline substituents at C-7 can significantly improve the activity against $\mathrm{H}$. pylori. It is well known and was previously highlighted by our group that highly lipophilic fluoroquinolone ligands improve antibacterial activity against Gram positive bacteria in particular, and to some extent against Gram negative bacteria Therefore, the activity of FQs $3 a-e$ could be explained to some extent by their high lipophilicity $[17,18]$. On the other hand, our group has emphasized that Gram negative activity was boosted through C-7 and C-8 hydrogen bond network of fluoroquinolone systems. The activity of compounds 3a-e against Gram negative $H$. pylori could also be attributed also to the extra hydrogen bond network that might be formed on C-7 (NH) and C-8 $\left(\mathrm{NO}_{2}\right)$ groups in our FQs. The extraordinary activity of compound $3 \mathrm{c}$ in particular against $H$. pylori can be explained by the additional H-B displayed by the para-methoxy group oxygen in the anisidine substituent of 3c. Again, same structural features of $3 \mathrm{c}$ and extra H-B of the methoxy can illuminate its unique inhibitory activity against $H$. pylori urease enzyme.

Fluoroquinolones $3 \mathbf{a}-\mathbf{e}$ are derivatives of clinically used antibacterial quinolones such as the drug ciprofloxacin. They exhibit the same nucleus-1-cyclopropyl-6-fluoro-4-oxo-1,4-dihydroquinoline3-carboxylic acid with aniline substituent instead of piperazine at C-7. Infact, the aniline system is known to be used in many drug interties as an analgesic drug. Therefore, we do expect them to suffer similar side effects and toxicity to known commercial FQs. 


\section{Materials and Methods}

\subsection{Materials and Instruments}

All chemicals, reagents, and solvents were of analytical grade and used directly without further purification. $p$-anisidine and $p$-toluidine were purchased from Fluka (Buchs, Switzerland). Reducing agent-anhydrous stannous chloride crystals-was purchased from Fluka (Buchs, Switzerland). Sodium nitrate was purchased from Sigma Aldrich (St. Louis, MO, USA). Melting points (mp) were determined in open capillaries on a Stuart scientific electro-thermal melting point apparatus (Stuart, Staffordshire, UK) and are uncorrected. Thin layer chromatography (TLC) was performed on $10 \times 10 \mathrm{~cm}^{2}$ aluminum plates pre-coated with fluorescent silica gel GF254 (ALBET, Germany), and was visualized using UV lamp (at $254 \mathrm{~nm}$ wavelength/short wavelength/ long wavelength). Mobile phase mixtures were: 94:5:1 chloroform-methanol-formic acid ( $\left.\mathrm{CHCl}_{3}-\mathrm{MeOH}-\mathrm{FA}\right)$ (system 1) and 50:50 (n-hexane-ethyl acetate) (system 2). Nuclear magnetic resonance spectra were recorded on a Varian Oxford-300 (300 MHz) spectrometer (ALT, CO, USA), and a Bruker, Avance DPX-300 spectrometer, a Bruker Avance-400 (400 MHz) Ultrashield spectrometer, and on a Bruker $500 \mathrm{MHz}$-Avance III (500 MHz) (Bruker, Billerica, MA, USA). Deuterated dimethylsulfoxide (DMSO- $d_{6}$ ) and deuterated chloroform $\left(\mathrm{CDCl}_{3}\right)$ were used as solvents in sample preparation, unless otherwise indicated. The chemical shifts were reported in ppm relative to tetramethylsilane (TMS), which was used as an internal reference standard. ${ }^{1} \mathrm{H}-\mathrm{NMR}$ data are reported as follows: chemical shift (ppm), multiplicity, coupling constant $(\mathrm{Hz})$, number of protons, the corresponding proton(s). Infrared (IR) spectra were recorded using a Shimadzu 8400F FT-IR spectrophotometer (Shimadzu, Kyoto, Japan). The samples were prepared as potassium bromide (KBr) (Sigma, St. Luis, MO, USA) disks. High-resolution mass spectra (HRMS) were measured in positive ion mode using electrospray ionization (ESI) technique by collision-induced dissociation on a Bruker APEX-4 (7 Tesla) instrument. The samples were dissolved in acetonitrile, diluted in spray solution (methanol/water 1:1 v/v+0.1 M formic acid) and infused using a syringe pump with a flow rate of $2 \mu \mathrm{L} / \mathrm{min}$. External calibration was conducted using arginine cluster in a mass range $m / z$ 175-871. Low-resolution mass spectra (LRMS) were measured by Applied Biosystems-MDS SCIEX API 3200 LC/MS/MS system (Applied Biosystems, Foster City, CA, USA), employing the positive mode using an electrospray ionizer (ESI) which was operated at 5.0-5.5 kV, with the capillary heater at $350{ }^{\circ} \mathrm{C}$, sheath gas pressure 45 psi and an ion trap analyzer. Molecular weight was recorded as atomic mass unit (AMU) + 1, as the positive mode of ESI adds 1 AMU to the molecular ion peak. Some compounds were recorded as AMU +2 , as the positive mode of ESI adds 1 AMU to the molecular ion peak and so does the iontrap analyzer.

\subsubsection{Synthesis of Novel Compounds $3 b$ and $3 c$}

Synthesis of Compound 1

Compound 1 was previously reported by our group [18]. It was synthesized following the same procedure, with slight modification.

Synthesis of New Compounds (Scheme 1)

Ethyl1-cyclopropyl-6-fluoro-7-[(4-methyl phenyl)amino]-8-nitro-4-oxo-1,4-dihydroquinoline-3-carboxylate (2b) (Scheme 1). Three equivalents of $p$-toluidine $(0.9 \mathrm{~g}, 8.4 \mathrm{mmol})$ were added into a solution containing ethyl7-chloro-1-cyclopropyl-6-fluoro-8-nitro-4-oxo-1,4-dihydroquinoline-3-carboxylate $(1.1 \mathrm{~g}, 2.8 \mathrm{mmol})$ and $10 \mathrm{~mL}$ of DMSO as a solvent and drops of pyridine, and was then refluxed at $65-70{ }^{\circ} \mathrm{C}$ under anhydrous conditions for 4-5 days. The reaction mixture was monitored until no starting material remained, then was left to crystallize at room temperature, and the product was filtered, soaked with petroleum ether, and left to dry in a dark place. Color of solid compound: orange; yield $\approx 50 \%(0.6 \mathrm{~g}) ; \mathrm{mp}: 227-230{ }^{\circ} \mathrm{C}$ (decomposition); $R_{\mathrm{f}}$ value in system $2=0.54 .{ }^{1} \mathrm{H}-\mathrm{NMR}$ $\left(300 \mathrm{MHz}, \mathrm{DMSO}-d_{6}\right): 0.97\left(\mathrm{~m}, 4 \mathrm{H}, \mathrm{H} 2-2^{\prime}, \mathrm{H} 2-3^{\prime}\right), 1.26\left(\mathrm{t}, J=7.2 \mathrm{~Hz}, 3 \mathrm{H}, \mathrm{CH}_{3} \mathrm{CH}_{2}\right), 2.21\left(\mathrm{~s}, 3 \mathrm{H}, \mathrm{Ar}^{-} \mathrm{CH}_{3}\right)$, 
$3.58\left(\mathrm{~m}, 1 \mathrm{H}, \mathrm{H}-1^{\prime}\right), 4.22\left(\mathrm{q}, J=7.2 \mathrm{~Hz}, 2 \mathrm{H}, \mathrm{CH}_{2} \mathrm{CH}_{3}\right), 6.85\left(\mathrm{dd}, J=2 \mathrm{~Hz}, 8.0 \mathrm{~Hz}, 2 \mathrm{H}, \mathrm{H}-2^{\prime \prime}, \mathrm{H}-6^{\prime \prime}\right)$, $7.01\left(\mathrm{dd}, J=2 \mathrm{~Hz}, 8.1 \mathrm{~Hz}, 2 \mathrm{H}, \mathrm{H}-3^{\prime \prime}, \mathrm{H}^{\prime \prime} 5^{\prime \prime}\right), 8.00\left(\mathrm{~d}, 3 \mathrm{~J}_{\mathrm{H}-\mathrm{F}}=11.7 \mathrm{~Hz}, 1 \mathrm{H}, \mathrm{H}-5\right), 8.54(\mathrm{~s}, 1 \mathrm{H}, \mathrm{H}-2), 8.60$ (br s, $1 \mathrm{H}, \mathrm{NH}$, exchangeable). ${ }^{13} \mathrm{C}-\mathrm{NMR}\left(75 \mathrm{MHz}, \mathrm{DMSO}-d_{6}\right)$ : $10.72\left(\mathrm{C}-2^{\prime}, \mathrm{C}-3^{\prime}\right), 14.91\left(\mathrm{CH}_{3} \mathrm{CH}_{2}\right), 21.0$ $\left(\mathrm{Ar}-\mathrm{CH}_{3}\right), 39.15\left(\mathrm{C}-1^{\prime}\right), 60.89\left(\mathrm{CH}_{2} \mathrm{CH}_{3}\right), 112.11(\mathrm{C}-3), 115.48$ (d, 2J $\left.J_{\mathrm{C}-\mathrm{F}}=21.5 \mathrm{~Hz}, \mathrm{C}-5\right), 119.02\left(\mathrm{C}-2^{\prime \prime}\right.$, C-6" $\left.{ }^{\prime \prime}\right), 124.15\left(\mathrm{~d}, 3 J_{\mathrm{C}-\mathrm{F}}=6 \mathrm{~Hz}, \mathrm{C}-4 \mathrm{a}\right), 129.85\left(\mathrm{C}-3^{\prime \prime}, \mathrm{C}-5^{\prime \prime}\right), 131.72\left(\mathrm{~d}, 2 J_{\mathrm{C}-\mathrm{F}}=16 \mathrm{~Hz}, \mathrm{C}-7\right), 132.04(\mathrm{C}-8 \mathrm{a})$, $133.43(\mathrm{C}-8), 135.89\left(\mathrm{C}-1^{\prime \prime}\right), 140.41\left(\mathrm{C}-4^{\prime \prime}\right), 151.99(\mathrm{C}-2), 152.83\left(\mathrm{~d}, 1 J_{\mathrm{C}-\mathrm{F}}=258 \mathrm{~Hz}, \mathrm{C}-6\right), 164.30\left(\mathrm{CO}_{2} \mathrm{Et}\right)$, $170.90\left(\mathrm{~d}, 4 J_{\mathrm{C}-\mathrm{F}}=2 \mathrm{~Hz}, \mathrm{C}-4\right) . \mathrm{IR}(\mathrm{KBr}): \vee 3430,3346,1731,1625,1523,1460,1319,1180,1029 \mathrm{~cm}^{-1}$. HRMS (ESI, +ve): calc. for $\mathrm{C}_{22} \mathrm{H}_{21} \mathrm{FN}_{3} \mathrm{O}_{5}[\mathrm{M}+\mathrm{H}]^{+}$(426.13870). Found 426.14598. Anal. Calcd for $\mathrm{C}_{22} \mathrm{H}_{20} \mathrm{FN}_{3} \mathrm{O}_{5}$ (425.41): $\mathrm{C}, 62.11 ; \mathrm{H}, 4.74 ; \mathrm{N}, 9.88$ Found $\mathrm{C}, 62.45 ; \mathrm{H}, 5.13 ; \mathrm{N}, 9.72$.

Ethyl 1-cyclopropyl-6-fluoro-7-[(4-methoxyphenyl)amino]-8-nitro-4-oxo-1,4-dihydroquinoline-3-carboxylate (2c) (Scheme 1). Three molar equivalents of $p$-anisidine $(3.1 \mathrm{~g}, 25.4 \mathrm{mmol})$ were added into a solution containing (1.3 g, $8.46 \mathrm{mmol})$ and $5-10 \mathrm{~mL}$ of DMSO as a solvent and drops of pyridine, and was then refluxed at $65-70{ }^{\circ} \mathrm{C}$ under anhydrous conditions for 2-3 days. The reaction mixture was monitored until no starting material remained, then was left to crystallize at room temperature. The product was filtered and left to dry in a dark place. Color of solid compound: red; yield $\approx 86 \%$ ( $3.2 \mathrm{~g})$; mp: $245-247{ }^{\circ} \mathrm{C}$ (decomposition); $R_{\mathrm{f}}$ value in system $2=0.48 .{ }^{1} \mathrm{H}-\mathrm{NMR}$ (300 MHz, DMSO): 0.92, 0.95 $\left(2 \mathrm{~m}, 4 \mathrm{H}, \mathrm{H} 2-2^{\prime}, \mathrm{H} 2-3^{\prime}\right), 1.25\left(\mathrm{t}, J=7.1 \mathrm{~Hz}, \mathrm{OCH}_{2} \mathrm{CH}_{3}\right), 3.56\left(\mathrm{~m}, 1 \mathrm{H}, \mathrm{H}-1^{\prime}\right), 3.68\left(\mathrm{~s}, 3 \mathrm{H}, \mathrm{OCH}_{3}\right), 4.2$ $\left(\mathrm{q}, J=7.74 \mathrm{~Hz}, 2 \mathrm{H}, \mathrm{OCH}_{2} \mathrm{CH}_{3}\right), 6.8\left(\mathrm{~d}, J=8.88 \mathrm{~Hz}, 2 \mathrm{H}, \mathrm{H}-2^{\prime \prime}, \mathrm{H}-6 "\right), 6.96\left(\mathrm{~d}, J=8.13 \mathrm{~Hz}, 2 \mathrm{H}, \mathrm{H}-3^{\prime \prime}, \mathrm{H}-5^{\prime \prime}\right)$, $7.92(\mathrm{~d}, 3 J \mathrm{H}-\mathrm{F}=12.3 \mathrm{~Hz}, 1 \mathrm{H}, \mathrm{H}-5), 8.52\left(\mathrm{br} \mathrm{s}, 1 \mathrm{H}, \mathrm{NH}\right.$, exchangeable), $8.61(\mathrm{~s}, 1 \mathrm{H}, \mathrm{H}-2) .{ }^{13} \mathrm{C}-\mathrm{NMR}$ (75 MHz, DMSO): $10.46\left(2 \mathrm{C}, \mathrm{C}-2^{\prime}, \mathrm{C}-3^{\prime}\right), 14.72\left(\mathrm{OCH}_{2} \mathrm{CH}_{3}\right), 39.09\left(\mathrm{C}-1^{\prime}\right), 55.74\left(\mathrm{OCH}_{3}\right), 60.7\left(\mathrm{OCH}_{2} \mathrm{CH}_{3}\right)$, $111.91(\mathrm{C}-3), 114.44\left(2 \mathrm{C}, \mathrm{C}-2^{\prime \prime}, \mathrm{C}-6^{\prime \prime}\right), 115.24\left(\mathrm{~d}, 2 J_{\mathrm{C}-\mathrm{F}}=21.15 \mathrm{~Hz}, \mathrm{C}-5\right), 121.51\left(2 \mathrm{C}, \mathrm{C}-3^{\prime \prime}, \mathrm{C}-5^{\prime \prime}\right), 122.85$ $(\mathrm{C}-4 \mathrm{a}), 132.43\left(\mathrm{~d}, 2 \mathrm{~J}_{\mathrm{C}-\mathrm{F}}=14.8 \mathrm{~Hz}, \mathrm{C}-7\right), 133.56(\mathrm{C}-8 \mathrm{a}), 135.35(\mathrm{C}-8), 135.38\left(\mathrm{C}-1^{\prime \prime}\right), 151.77(\mathrm{C}-2), 151.9$ $\left(\mathrm{d}, 1 J_{\mathrm{C}-\mathrm{F}}=250.65 \mathrm{~Hz}, \mathrm{C}-6\right), 155.95\left(\mathrm{C}-4^{\prime \prime}\right), 164.11\left(\mathrm{CO}_{2} \mathrm{Et}\right), 170.66(\mathrm{C}-4) . \mathrm{IR}(\mathrm{KBr}): v \mathrm{3} 425,3363,1728$, 1610, 1500, 1435, 1327, 1080, $1033 \mathrm{~cm}^{-1}$. HRMS (ESI, +ve): calc. for $\mathrm{C}_{22} \mathrm{H}_{20} \mathrm{FN}_{3} \mathrm{NaO}_{6}[\mathrm{M}+\mathrm{Na}]^{+}$ (464.12338). Found 464.12283. LRMS (ES, +ve) $m / z$ calc. for $\mathrm{C}_{21} \mathrm{H}_{24} \mathrm{FN}_{3} \mathrm{O}_{5}$ (441.13): Found $443.4(88 \%$, $\mathrm{M}+2), 442.0(100 \%, \mathrm{M}+1), 428.5(2 \%), 412.6$ (2\%), $397.6(7 \%), 396.6(35 \%), 377.2(1 \%), 335.2(9 \%), 338.1$ (1\%), $322.1(1 \%), 261.4(1 \%), 102.1(2 \%), 78.8(1 \%), 74.3(5 \%), 60.8(1 \%), 59.2(8 \%)$. Anal. Calcd for $\mathrm{C}_{22} \mathrm{H}_{20} \mathrm{FN}_{3} \mathrm{O}_{5}$ (441.41): C, 59.86; H, 4.57; N, 9.52 Found $\mathrm{C}, 60.04 ; \mathrm{H}, 4.32 ; \mathrm{N}, 9.85$.

1-Cyclopropyl-6-fluoro-7-[(4-methylphenyl)amino]-8-nitro-4-oxo-1,4-dihydroquinoline-3-carboxylic acid (3b) (Scheme 1). A vigorously stirred suspension of ethyl 1-cyclopropyl-6-fluoro-7-[(4-methyl phenyl)amino]-8-nitro-4-oxo-1,4-dihydroquinoline-3-carboxylate $(\mathbf{2 b}, 0.28 \mathrm{mmol}, 0.12 \mathrm{~g})$ was dissolved in a mixture of absolute ethanol $(2 \mathrm{~mL})$ and $12 \mathrm{~N} \mathrm{HCl}(5 \mathrm{~mL})$ under reflux at $80-90^{\circ} \mathrm{C}$ for $24-48 \mathrm{~h}$, and the reaction was monitored by TLC. At the end of the reaction, the reaction mixture was poured on crushed ice to precipitate a pure product that was collected by filtration and left to dry at room temperature. Color of solid compound: bright orange; yield $\approx 55.4 \%(0.062 \mathrm{~g}) ; \mathrm{mp}: 243-245{ }^{\circ} \mathrm{C}$. ${ }^{1} \mathrm{H}-\mathrm{NMR}\left(300 \mathrm{MHz}, \mathrm{CDCl}_{3}\right): 0.87,1.14\left(2 \mathrm{~m}, 4 \mathrm{H}, \mathrm{H} 2-2^{\prime}, \mathrm{H} 2-3^{\prime}\right), 2.29\left(\mathrm{~s}, 3 \mathrm{H}, \mathrm{Ar}^{-\mathrm{CH}_{3}}\right), 3.69(\mathrm{~m}, 1 \mathrm{H}$, H-1 $), 6.90\left(\mathrm{~d}, J=75 \mathrm{~Hz}, 2 \mathrm{H}, \mathrm{H}-2^{\prime \prime}, \mathrm{H}-6^{\prime \prime}\right), 7.09$ (d, J = 7.8 Hz, 2H, H-3", $\left.\mathrm{H}-5^{\prime \prime}\right), 8.00$ (br s, 1H, NH, exchangeable), 8.12 (d,3JH-F = $12 \mathrm{~Hz}, 1 \mathrm{H}, \mathrm{H}-5), 8.81$ (s, 1H, H-2), 14.50 (br s, $1 \mathrm{H}, \mathrm{COOH}) .{ }^{13} \mathrm{C}-\mathrm{NMR}$ (75 MHz, DMSO- $\left.d_{6}\right): 10.54\left(\mathrm{C}-2^{\prime}, \mathrm{C}-3^{\prime}\right), 20.9\left(\mathrm{CH}_{3}\right), 40.4\left(\mathrm{C}-1^{\prime}\right), 109.4(\mathrm{C}-3), 114.7\left(\mathrm{~d}, 2 J_{\mathrm{C}-\mathrm{F}}=21.83 \mathrm{~Hz}\right.$, C-5), $119.2\left(\mathrm{C}-4^{\prime \prime}\right), 120.0\left(\mathrm{C}-2^{\prime \prime}, \mathrm{C}-6^{\prime \prime}\right), 120.6(\mathrm{~d}, 3 \mathrm{~J} \mathrm{C}-\mathrm{F}=7.8 \mathrm{~Hz}, \mathrm{C}-4 \mathrm{a}), 129.7\left(\mathrm{C}-3^{\prime \prime}, \mathrm{C}-5^{\prime \prime}\right), 133.0(\mathrm{C}-8 \mathrm{a})$, $133.5\left(\mathrm{~d}, 2 J_{\mathrm{C}-\mathrm{F}}=15.4 \mathrm{~Hz}, \mathrm{C}-7\right), 134.3(\mathrm{C}-8), 139.4\left(\mathrm{C}-1^{\prime \prime}\right), 152.5(\mathrm{C}-2), 152.8\left(\mathrm{~d}, 1 J_{\mathrm{C}-\mathrm{F}}=253 \mathrm{~Hz}, \mathrm{C}-6\right), 165.4$ (COOH), 175.8 (C-4). IR (KBr): $v$ 3433, 3363, 3063, 2924, 1728, 1620, 1519, 1458, 1319, 1242, $1103 \mathrm{~cm}^{-1}$. HRMS (ESI, +ve): calc. for $\mathrm{C}_{20} \mathrm{H}_{16} \mathrm{FN}_{3} \mathrm{O}_{5}[\mathrm{M}+\mathrm{H}]^{+}$(397.10740). Found 397.10012. Anal. Calcd for $\mathrm{C}_{20} \mathrm{H}_{16} \mathrm{FN}_{3} \mathrm{O}_{5}$ (397.36): $\mathrm{C}, 60.45 ; \mathrm{H}, 4.06 ; \mathrm{N}, 10.57$ Found $\mathrm{C}, 60.86 ; \mathrm{H}, 4.41 ; \mathrm{N}, 10.79$.

1-Cyclopropyl-6-fluoro-7-(4-methoxy-phenylamino)-8-nitro-4-oxo-1,4-dihydro-quinoline-3-carboxylic acid (3c) (Scheme 1). A vigorously stirred suspension of (2c, $0.6 \mathrm{~g}, 1.4 \mathrm{mmol})$ was dissolved in $12 \mathrm{~mL}$ mixture ofabsolute ethanol and $12 \mathrm{~N} \mathrm{HCl}$ under reflux at $80-90^{\circ} \mathrm{C}$ for $24-48 \mathrm{~h}$, and the reaction was monitored by TLC. At the end of the reaction, the reaction mixture was poured on crushed ice to precipitate a pure product that was collected by filtration and left to dry at room temperature. Color of product: deep 
orange; yield $\approx 69 \%(0.4 \mathrm{~g}) ; \mathrm{mp}: 210-215^{\circ} \mathrm{C} ; R_{\mathrm{f}}$ value in system $1=0.5 .{ }^{1} \mathrm{H}-\mathrm{NMR}\left(300 \mathrm{MHz}, \mathrm{DMSO}-d_{6}\right)$ : 1.03, $1.21\left(\mathrm{~m}, 4 \mathrm{H}, \mathrm{H} 2-2^{\prime}, \mathrm{H} 2-3^{\prime}\right), 3.62\left(\mathrm{~m}, 1 \mathrm{H}, \mathrm{NCH}^{\prime}{ }^{\prime}\right), 3.74\left(\mathrm{~s}, 3 \mathrm{H}, \mathrm{OCH}_{3}\right), 7.05\left(\mathrm{~d}, J=8.7 \mathrm{~Hz}, 2 \mathrm{H}, \mathrm{H}-2^{\prime \prime}\right.$, H-6" $\left.{ }^{\prime \prime}\right), 7.36\left(\mathrm{~d}, \mathrm{~J}=8.8 \mathrm{~Hz}, 2 \mathrm{H}, \mathrm{H}-3^{\prime \prime}, \mathrm{H}-5^{\prime \prime}\right), 7.96\left(\mathrm{~d}, 3 J_{\mathrm{H}-\mathrm{F}}=11.7 \mathrm{~Hz}, 1 \mathrm{H}, \mathrm{H}-5\right), 8.56$ (s, 1H, H-2), 8.85 (br s, $1 \mathrm{H}, \mathrm{NH}$, exchangeable), 14.66 (br s, $1 \mathrm{H}, \mathrm{COOH}) .{ }^{13} \mathrm{C}-\mathrm{NMR}\left(75 \mathrm{MHz}, \mathrm{DMSO}-d_{6}\right): 10.43\left(2 \mathrm{C}, \mathrm{C}-2^{\prime}, \mathrm{C}-3^{\prime}\right)$, $39.85\left(\mathrm{C}-1^{\prime}\right), 55.73\left(\mathrm{OCH}_{3}\right), 106.84\left(\mathrm{~d}, 2 J_{\mathrm{C}-\mathrm{F}}=19 \mathrm{~Hz}, \mathrm{C}-5\right), 109.35(\mathrm{C}-3), 114.13\left(2 \mathrm{C}, \mathrm{C}-2^{\prime \prime}, \mathrm{C}^{\prime \prime} 6^{\prime \prime}\right), 115.13$ (2C, C-3" $\left.{ }^{\prime \prime}, C-5^{\prime \prime}\right), 122.65(\mathrm{C}-4 \mathrm{a}), 124.78(\mathrm{C}-8 \mathrm{a}), 132.45(\mathrm{C}-8), 134.46\left(\mathrm{C}-1^{\prime \prime}\right), 140.33(\mathrm{C}-7), 148.01(\mathrm{C}-2)$, $152.3\left(\mathrm{~d}, 1 J_{\mathrm{C}-\mathrm{F}}=260 \mathrm{~Hz}, \mathrm{C}-6\right), 156.65\left(\mathrm{C}-4^{\prime \prime}\right), 166.59(\mathrm{COOH}), 176.45(\mathrm{C}-4) . \mathrm{IR}(\mathrm{KBr}): v$ 3363, 3063, 2924, $2854,1728,1627,1512,1458,1319,1242,1033 \mathrm{~cm}^{-1}$. HRMS (ESI +ve): calc. for $\mathrm{C}_{20} \mathrm{H}_{17} \mathrm{FN}_{3} \mathrm{O}_{6}[\mathrm{M}+\mathrm{H}]^{+}$ (414.11014). Found 414.10959. LRMS (ESI +ve): calc. for $\mathrm{C}_{20} \mathrm{H}_{17} \mathrm{FN}_{3} \mathrm{O}_{6}(413.1)$ Found $414.4(5 \%, \mathrm{M}+1)$, 412.9 (76\%), 384.2 (29\%), 379.8 (1\%), 367.4 (100\%), $365.3(13 \%), 361.3(9 \%), 339.2$ (58\%), $331.7(8 \%)$, 324.6 (15\%), 321.2 (9\%), 282.0 (3\%), 240.9 (7\%), 225.0 (4\%), $217.4(2 \%), 187.2$ (1\%), $145.0(2 \%), 130.3$ (13\%), $123.4(7 \%), 107.1$ (1\%), 101.0 (48\%), 78.9 (93\%), 74.5 (7\%), $63.9(13 \%), 59.0$ (28\%). Anal. Calcd for $\mathrm{C}_{20} \mathrm{H}_{16} \mathrm{FN}_{3} \mathrm{O}_{6}$ (413.36): C, 58.11; H, 3.80; N, 10.17 Found C, 57.86; H, 4.11; N, 10.55.

\subsection{Microbiological Methods and Anti-Microbial Assays}

\subsubsection{Bacterial Strains and Growth Conditions}

Twelve H. pylori clinical isolates and one reference strain of H. pylori (NCTC 11916) were used in this study. The clinical strains were isolated from gastric biopsy samples obtained by a gastroenterologist of the Jordan University Hospital during a routine endoscopy. The gastric biopsy material was processed according to the standard methodology. Briefly, each biopsy for culture was homogenized using a tissue homogenizer (IKA, Staufen, Germany). Aliquots of $100 \mu \mathrm{L}$ of the homogenate were primarily cultured on Columbia blood agar (Oxoid, Hampshire, UK) supplemented with $7 \%(v / v)$ horse blood and Dent selective supplement (Oxoid, Hampshire, UK). Subcultures of the bacteria were performed using the same plates but without the Dent supplement. All of the plates were incubated at $37^{\circ} \mathrm{C}$ under microaerophilic conditions using CampyGen atmosphere generating system (Oxoid, Hampshire, UK) in anaerobic jars for 5-7 days. Growth of H. pylori was confirmed according to colony morphology, Gram staining, microaerophilic growth $\left(\right.$ at $\left.37^{\circ} \mathrm{C}\right)$, biochemical tests (positive for oxidase, catalase, and urease), and subsequently by standard PCR of $16 \mathrm{~S}$ ribosomal DNA test [21]. H. pylori cultures were stored at $-70{ }^{\circ} \mathrm{C}$ in Trypticase soy broth (Oxoid, Hampshire, UK) containing 10\% (v/v) fetal calf serum (PAA, Pasching, Austria) and 15\% glycerol.

\subsubsection{Antimicrobial Susceptibility Testing and Minimal Inhibitory Concentration Determination}

Bacterial suspensions were prepared to the 2 McFarland's standard and subsequently uniformly spread on a solid growth medium in a Petri dish. Sterile paper disks $(6 \mathrm{~mm}$ in diameter; Oxoid, Hampshire, UK) were impregnated with $25 \mu \mathrm{L}$ of each compound, and were placed on the surface of each agar plate. Plates were incubated for 5-7 days under appropriate cultivation conditions. Antibacterial activity was determined by the production of an inhibition zone around the impregnated disc with the compounds. Disks impregnated with DMSO served as negative controls, and disks with standard antibiotics (ciprofloxacin and metronidazole, Oxoid, Hampshire, UK) served as positive controls. The minimal inhibitory concentrations (MICs) of each extract were determined by the two-fold agar dilution method as previously described [22]. In brief, each compound was serially diluted in DMSO and incorporated to molten Columbia blood agar plates supplemented with $7 \%(v / v)$ horse blood. Spot of $H$. pylori $\left(1 \times 10^{5} \mathrm{CFU}\right)$ was applied on the surface of each plate, and the growth of visible colonies was determined after 7 days of incubation at $37^{\circ} \mathrm{C}$ under microaerophilic conditions.

MIC was recorded as the lowest concentration that inhibited the visible growth of organisms; the plates with the standard antibiotics served as positive controls, and plates with DMSO served as negative controls. Triplicates of each tested compound were performed, and the average of the results was taken. 


\subsubsection{Determination of in Vitro Interaction}

Antimicrobial interactions between each compound and metronidazole against three strains (two clinical isolates and one reference strain) of $H$. pylori were evaluated by the standard checkerboard titration method [23]. Each compound and metronidazole was dissolved in DMSO and distilled water, respectively. The bacterial inoculum, media, and culture conditions were the same as those described for the MIC determination mentioned above. Experiments were performed in triplicate.

The fractional inhibitory concentrations (FICs) were calculated as follows:

- $\quad \mathrm{FIC}=(\mathrm{MIC}$ of drug $\mathrm{A}$ in combination/MIC of drug A alone $)+($ MIC of drug B in combination/MIC of drug B alone).

- The FIC indices were interpreted as follows: $\leq 0.5$, synergy; 0.5-1, additive; $1-4.0$, indifference; $>4.0$, antagonism.

\subsection{Urease Inhibition Assay}

Urease inhibition was performed as described elsewhere [24]. Briefly, $10 \mu \mathrm{L}$ of $1 \times 10^{8} \mathrm{CFU} / \mathrm{mL}$ H. pylori suspension was incubated with equal amount of serially diluted compound in 96-well microplates for $30 \mathrm{~min}$ at $37^{\circ} \mathrm{C}$. Subsequently, $200 \mu \mathrm{L}$ of detection reagent composed of $50 \mathrm{mM}$ phosphate buffer, pH 6.8 containing $500 \mathrm{mM}$ urea and $0.02 \%$ phenol red was added to each well. The color development was measured at $555 \mathrm{~nm}$ in 5 min intervals. Controls included bacteria with the reagent, and reagent with each compound. The percentage of inhibition was calculated by the equation $\%$ inhibition $=[$ (activity without compound - activity with compound $) /$ (activity without compound) $] \times 100$. The activity was compared to a reference urease inhibitor-acetohdyroxamicacid (Sigma-Aldrich, St. Louis, MI, USA).

\section{Conclusions}

In conclusion, this work successfully introduced new 8-nitro-fluoroquinolone derivatives utilizing a new procedure developed within the course of this work. The fluoroquinolone derivatives were fully identified and characterized using NMR, IR, electrochemical analysis (EA), and MS. The antimicrobial properties of all pure compounds were evaluated against $H$. pylori. Although the selected structures did not follow a specific pattern (structure), it could be suggested that different hydrophilic/lipophilic properties and different intra-cellular targets are considered for further investigation of the mechanism of antibacterial action

The results clearly indicate that all new compounds have interesting antimicrobial activity against metronidazole-resistant $H$. pylori. In addition, these compounds could be considered good candidates for studying the combination effect with metronidazole in vivo for future potential as alternatives in the triple therapy regimen used in clinical practice.

Acknowledgments: Authors wish to thank Deanship of Academic Research, Deanship of Post Graduate Studies and the Faculty of Pharmacy, University of Jordan, Amman, Jordan for providing necessary facilities and funds for conducting this research. Authors wish also to thank the Jordan Company for antibody production for their technical support and providing us with the H. pylori control strain.

Author Contributions: Luay Abu-Qatouseh and Rula Darwish conceived and designed the microbiological and biological activities, Yusuf Al-Hiari and Talal Aburjai designed the chemical synthesis and their corresponding experiments; Mohammad Abu-Sini and Amal Mayyas performed the experiments. Rula Darwish and Yusuf Al-Hiari analyzed the data; Talal Aburjai and Luay Abu-Qatouseh contributed by providing reagents/materials/analysis tools; Luay Abu-Qatouseh wrote the paper.

Conflicts of Interest: The authors declare no conflict of interest. The founding sponsors had no role in the design of the study; in the collection, analyses, or interpretation of data; in the writing of the manuscript, and in the decision to publish the results. 


\section{References}

1. Hayama, M.; Kawakami, Y.; Kaneko, Y.; Sano, K.; Ota, H. Helicobacter pylori infection increases cell kinetics in human gastric epithelial cells without adhering to proliferating cells. J. Cell Mol. Med. 2005, 9, 746-747. [CrossRef] [PubMed]

2. Kalali, B.; Mejías-Luque, R.; Javaheri, A.; Gerhard, M. H. pylori virulence factors: Influence on immune system and pathology. Mediat. Inflamm. 2014, 2014, 6642-6651. [CrossRef] [PubMed]

3. Shetty, V.; Ballal, M.; Lingadakai, R.; Mukhopadhyay, A. Determination of Helicobacter pylori virulence genes in clinical isolates of symptomatic patients from South Coastal Region of Karnataka-A preliminary work. Austin J. Gastroenterol. 2015, 2, 1031.

4. Marshall, B.J.; Armstrong, J.A.; McGechie, D.B.; Glancy, R.J. Attempt to fulfil Koch's postulates for pyloric Campylobacter. Med. J. Aust. 1985, 142, 436-439. [PubMed]

5. Mendes, L.T.; Attygalle, A.D.; Wotherspoon, A.C. Helicobacter pylori infection in gastric extranodal marginal zone lymphoma of mucosa-associated lymphoid tissue (MALT) lymphoma: A re-evaluation. Gut. 2014, 63, 1526-1527. [CrossRef] [PubMed]

6. Asaka, M.; Sugiyama, T.; Kato, M.; Satoh, K.; Kuwayama, H.; Fukuda, Y.; Fujioka, T.; Takemoto, T.; Kimura, K.; Shimoyama, T.; et al. A multicenter, double-blind study on triple therapy with lansoprazole, amoxicillin and clarithromycin for eradication of Helicobacter pylori in Japanese peptic ulcer patients. Helicobacter 2001, 6, 254-261. [CrossRef] [PubMed]

7. O'Connor, A.; Molina-Infante, J.; Gisbert, J.P.; O'Morain, C. Treatment of Helicobacter pylori infection. Helicobacter 2013, 18, 58-65. [CrossRef] [PubMed]

8. Saad, A.M.; Choudhary, A.; Bechtold, M.L. Effect of Helicobacter pylori treatment on gastroesophageal reflux disease (GERD): Meta-analysis of randomized controlled trials. Scand. J. Gastroenterol. 2012, 47, 129-135. [CrossRef] [PubMed]

9. Ierardi, E.; Giangaspero, A.; Losurdo, G.; Giorgio, F.; Amoruso, A.; de Francesco, V. Quadruple rescue therapy after first and second line failure for Helicobacter pylori treatment: Comparison between two tetracycline-based regimens. J. Gastrointestin. Liver Dis. 2014, 23, 367-370. [PubMed]

10. Megraud, F.; Coenen, S.; Versporten, A.; Kist, M.; Lopez-Brea, M.; Hirschl, A.; Albrecht, P. Helicobacter pylori resistance to antibiotics in Europe and its relationship to antibiotic consumption. Gut 2013, 62, 34-42. [CrossRef] [PubMed]

11. Wise, R.; Andrews, J.M.; Edwards, L.J. In vitro activity of Bay 09867, a new quinoline derivative, compared with those of other antimicrobial agents. Antimicrob. Agents Chemother. 1983, 23, 559-564. [CrossRef] [PubMed]

12. Felmingham, D.; O’Hare, M.D.; Robbins, M.J.; Wall, R.A.; Williams, A.H.; Cremer, A.W.; Ridgeway, G.L.; Gruneberg, R.N. Comparative in vitro studies with 4-quinolone antimicrobials. Drugs Exp. Clin. Res. 1985, 11,317-329. [PubMed]

13. Maurer, F.; Grohe, K. 2,4-Dichloro-5-fluorobenzoic acid. Chem. Abstr. 1986, 105, 97158e.

14. Petersen, U.; Bartel, S.; Bremm, K.D.; Himmler, T.; Krebs, A.; Schenke, T. The synthesis and biological properties of 6-fluoroquinolonecarboxylic acids. Bull. Soc. Chim. Belg. 1996, 105, 683-699.

15. Vilaichone, R.K.; Gumnarai, P.; Ratanachu-ek, T.; Mahachai, V. Nationwide survey of Helicobacter pylori antibiotic resistance in Thailand. Diagn. Microbiol. Infect. Dis. 2013, 77, 346-349. [CrossRef] [PubMed]

16. Cheng, A.; Sheng, W.H.; Liou, J.M.; Wang, H.P.; Wu, M.S.; Lin, J.T.; Chang, S.C. Comparative in vitro antimicrobial susceptibility and synergistic activity of antimicrobial combinations against Helicobacter pylori isolates in Taiwan. J. Microbiol. Immunol. Infect. 2015, 48, 72-79. [CrossRef] [PubMed]

17. Al-Hiari, Y.M.; Qandil, A.M.; Al-Zoubi, R.M.; Alzweiri, M.H.; Darwish, R.M.; Shattat, G.F.; Al-Qirim, T.M. Synthesis and antibacterial activity of novel 7-haloanilino-8-nitrofluoroquinolone derivatives. Med. Chem. Res. 2012, 21, 1734-1740. [CrossRef]

18. Al-Hiari, Y.M.; Al-Mazari, I.S.; Shakya, A.K.; Darwish, R.M.; Abu-Dahab, R. Synthesis and antibacterial properties of new 8-nitro fluoroquinolone derivatives. Molecules 2007, 12, 1240-1258. [CrossRef] [PubMed]

19. Malfertheiner, P.; Megraud, F.; O'Morain, C.A.; Atherton, J.; Axon, A.T.; Bazzoli, F.; El-Omar, E.M. Management of Helicobacter pylori infection-The Maastricht IV/Florence consensus report. Gut 2012, 61, 646-664. [CrossRef] [PubMed] 
20. Abu-Qatouseh, L.F.; Boutennone, H.; Boussouf, L.; Madani, K.; Shihab, P.; Al-Qaoud, K. In Vitro anti-Helicobacter pylori and urease inhibitory effects of polyphenolic extracts of local herbs from Algeria. IAJAA 2014, 3, 1-4.

21. Yakoob, J.; Abbas, Z.; Khan, R.; Naz, S.; Ahmad, Z.; Islam, M.; Awan, S.; Jafri, F.; Jafri, W. Prevalence of non Helicobacter pylori species in patients presenting with dyspepsia. BMC Gastroenterol. 2012, 12, 3. [CrossRef] [PubMed]

22. Klancnik, A.; Piskernik, S.; Jersek, B.; Mozina, S.S. Evaluation of diffusion and dilution methods to determine the antibacterial activity of plant extracts. J. Microbiol. Methods 2010, 81, 121-126. [CrossRef] [PubMed]

23. Koga, T.; Inoue, H.; Ishii, C.; Okazaki, Y.; Domon, H.; Utsui, Y. Effect of plaunotol in combination with clarithromycin or amoxicillin on Helicobacter pylori in vitro and in vivo. J. Antimicrob. Chemother. 2002, 50, 133-136. [CrossRef] [PubMed]

24. Nagata, K.; Mizuta, T.; Tonokatu, Y.; Fukuda, Y.; Okamura, H.; Hayashi, T.; Tamura, T. Monoclonal Antibodies against the Native Urease of Helicobacter pylori: Synergistic Inhibition of Urease Activity by Monoclonal Antibody Combinations. Infect. Immun. 1992, 60, 4826-4831. [PubMed]

Sample Availability: SampleAvailability: Samples of the compounds are not available from the authors.

(C) 2017 by the authors; licensee MDPI, Basel, Switzerland. This article is an open access article distributed under the terms and conditions of the Creative Commons Attribution (CC-BY) license (http://creativecommons.org/licenses/by/4.0/). 